\title{
Early Life Irradiation-Induced Hypoplasia and Impairment of Neurogenesis in the Dentate Gyrus and Adult Depression Are Mediated by MicroRNA-34a-5p/T-Cell Intracytoplasmic Antigen-1 Pathway
}

\author{
Hong Wang ${ }^{1,+}+\mathbb{D}$, Zhaowu Ma ${ }^{2,+}{ }^{-}$, Hongyuan Shen ${ }^{1}$, Zijun $W^{3}{ }^{3}$, Lian Liu ${ }^{2}$, Boxu Ren ${ }^{2}$, Peiyan Wong ${ }^{4}$, \\ Gautam Sethi ${ }^{5, *}$ and Feng Ru Tang ${ }^{1, *(\mathbb{D}}$
}

1 Radiation Physiology Lab, Singapore Nuclear Research and Safety Initiative, National University of Singapore, Singapore 138602, Singapore; snrwh@nus.edu.sg (H.W.); snrsh@nus.edu.sg (H.S.)

2 The School of Basic Medicine, Health Science Center, Yangtze University, 1 Nanhuan Road, Jingzhou 434023, China; zhaowu823@126.com (Z.M.); zifanqie_00@126.com (L.L.); boxuren188@163.com (B.R.)

3 Huaxi MR Research Center (HMRRC), Functional and Molecular Imaging Key Laboratory of Sichuan Province, Department of Radiology, West China Hospital, Sichuan University, Chengdu 610017, China; 2019324020159@stu.scu.edu.cn

check for updates

Citation: Wang, H.; Ma, Z.; Shen, H.; Wu, Z.; Liu, L.; Ren, B.; Wong, P.; Sethi, G.; Tang, F.R. Early Life Irradiation-Induced Hypoplasia and Impairment of Neurogenesis in the Dentate Gyrus and Adult Depression Are Mediated by MicroRNA-34a-5p/T-Cell Intracytoplasmic Antigen-1 Pathway. Cells 2021, 10, 2476. https://doi.org/10.3390/ cells10092476

Academic Editor: Thorsten R. Doeppner

Received: 24 August 2021 Accepted: 15 September 2021 Published: 18 September 2021

Publisher's Note: MDPI stays neutral with regard to jurisdictional claims in published maps and institutional affiliations.

Copyright: (c) 2021 by the authors. Licensee MDPI, Basel, Switzerland. This article is an open access article distributed under the terms and conditions of the Creative Commons Attribution (CC BY) license (https:/ / creativecommons.org/licenses/by/ $4.0 /)$.
4 Neuroscience Phenotyping Core, Department of Pharmacology, Yong Loo Lin School of Medicine, National University of Singapore, Singapore 117456, Singapore; wong_peiyan@nus.edu.sg

5 Department of Pharmacology, Yong Loo Lin School of Medicine, National University of Singapore, Singapore 117600, Singapore

* Correspondence: phcgs@nus.edu.sg (G.S.); tangfr@gmail.com (F.T.)

+ These authors contributed equally to this work.

Abstract: Early life radiation exposure causes abnormal brain development, leading to adult depression. However, few studies have been conducted to explore pre- or post-natal irradiation-induced depression-related neuropathological changes. Relevant molecular mechanisms are also poorly understood. We induced adult depression by irradiation of mice at postnatal day 3 (P3) to reveal hippocampal neuropathological changes and investigate their molecular mechanism, focusing on MicroRNA (miR) and its target mRNA and protein. P3 mice were irradiated by $\gamma$-rays with 5Gy, and euthanized at 1, 7 and 120 days after irradiation. A behavioral test was conducted before the animals were euthanized at 120 days after irradiation. The animal brains were used for different studies including immunohistochemistry, CAP-miRSeq, Real-Time Quantitative Reverse Transcription PCR (qRT-PCR) and western blotting. The interaction of miR-34a-5p and its target T-cell intracytoplasmic antigen-1 (Tia1) was confirmed by luciferase reporter assay. Overexpression of Tia1 in a neural stem cell (NSC) model was used to further validate findings from the mouse model. Irradiation with 5 Gy at P3 induced depression in adult mice. Animal hippocampal pathological changes included hypoplasia of the infrapyramidal blade of the stratum granulosum, aberrant and impaired cell division, and neurogenesis in the dentate gyrus. At the molecular level, upregulation of miR-34a-5p and downregulation of Tia1 mRNA were observed in both animal and neural stem cell models. The luciferase reporter assay and gene transfection studies further confirmed a direct interaction between miR-34a-5p and Tia1. Our results indicate that the early life $\gamma$-radiation-activated miR-34a-5p/Tia1 pathway is involved in the pathogenesis of adult depression. This novel finding may provide a new therapeutic target by inhibiting the miR-34a-5p/Tia1 pathway to prevent radiation-induced pathogenesis of depression.

Keywords: $\gamma$-irradiation; depression; neurogenesis; miR-34a-5p; Tia1 


\section{Introduction}

Depression is one of the most significant and long-term consequence of radiation exposure among the survivors of nuclear accidents or wars [1-4] and is associated with brain-structural changes including reduced dentate gyrus size and altered hippocampal volume [5-12]. The small dentate gyrus may be caused by the impairment of neurogenesis, and it supports the "neurogenesis hypothesis of depression" [13] and the "cellular plasticity hypothesis of depression" [14]. The therapeutic effect achieved by promoting neurogenesis to improve depression symptoms further supports the "neurogenesis hypothesis of depression" $[11,15,16]$. These neuropathological changes may be induced by pre- or post-natal radiation exposure [17-23]. While it has been well documented that oxidative stress and neuroinflammation are involved in radiation-induced brain damage, whether brain microRNA (miR) and its target gene are involved in radiation-induced hippocampal structural changes and subsequent depression remains unknown.

Recent studies suggest that brain miR changes may be involved in depression-like behavior or depressive symptoms [24-28]. For instance, miR-15b is upregulated in the medial prefrontal cortex of mice with depression-like behavior and inhibits neuronal progenitor proliferation [29]. miR-124 serves as a putative therapeutic target and a biomarker for depression [30], and the inhibition of miR-124 could reduce depression-like behavior in animals [31-33]. miR-34a was shown to be significantly up-regulated in a mouse model [34] and in patients [35] with depression. In the latter, the serum level of miR-34a-5p was positively correlated with the severity of depression [35]. It suggests that further study of brain miR-34a-5p and its target gene may be needed in order to correlate serum miR-34a-5p changes to brain changes. Establishment of the relationship between brain miR-34a-5p, its target gene and the impairment of neurogenesis or small dentate gyrus may provide new clues for understanding the mechanism of the development of depression and for novel therapeutic approaches to prevent the genesis of depression.

The formation of stress granules (SGs) is a key event in cells after exposure to physiological or environmental stressors. The suppression of SG generation may underlie the neuronal cell death observed in neurodegenerative diseases [36]. T-cell intracytoplasmic antigen-1 (Tia1), as an RNA-binding protein in brain tissues, functions as a posttranscriptional regulator of gene expression. It aggregates to form SG following cellular damage, which is strongly linked to the pathophysiology of neurodegeneration [37,38]. Evidence has demonstrated that Tia1 is a potential biomarker in the brain of a mouse model for Alzheimer's disease [39]. One study predicts that miR-34a may target Tia1 in the inhibition of myeloid-derived suppressor cell apoptosis [40]. However, the function of Tia1 on gamma irradiation-induced cellular damage has been poorly investigated.

This study aimed to examine if the acute irradiation with 5Gy at postnatal day 3 (P3) induced adult depression. The progressive neuropathological changes in the dentate gyrus, in particular, neurogenesis at 1, 7, and 120 day(s) after radiation exposure, were also investigated. We also elucidated the molecular mechanisms involved in radiationinduced neuropathological and neuropsychological changes, focusing on the miR and its targeted gene. We found that the $\gamma$-irradiation-activated miR-34a-5p/T-cell intracytoplasmic antigen-1 (Tia1) pathway in P3 mice was involved in the hypoplasia of the infrapyramidal blade of the stratum granulosum and the impairment of neurogenesis in the dentate gyrus and, therefore, participated in the pathogenesis of adult depression.

\section{Materials and Methods}

\subsection{Radiation Exposure}

Balb/c mice were purchased from InVivos Pte. Ltd. (Singapore) and housed with free access to water and food in the Comparative Medicine Facility, National University of Singapore. The experimental protocols were approved by the Institutional Animal Care and Use Committee (IACUC), National University of Singapore (IACUC number: R151576). Mice were exposed to $5 \mathrm{~Gy}$ gamma radiation (dose rate: $3.33 \mathrm{~Gy} / \mathrm{m}$ ) in a $\gamma$-Irradiator (BIOBEAM GM 8000, The Gamma-Service Medical GmbH, Leipzig, Germany) at postnatal 
day 3 (P3). Animals were euthanized at 1, 7 and 120 day(s) after irradiation and brain samples were collected for different experimental studies. For animals kept for 120 days, different neurobehavioral tests were performed before the animals were euthanized.

\subsection{Behavioral Tests}

\subsubsection{Open Field (Locomotor) Test}

Mice were allowed to explore freely for $1 \mathrm{~h}$ in a square open field $(40 \mathrm{~cm} \times 40 \mathrm{~cm})$ cage. Locomotor activity in terms of total distance travelled was recorded using the TopScan Behavioural Analysing system (Cleversys, Reston, VA, USA).

\subsubsection{Tail Suspension Test}

Mice were suspended by their tails for 6 min [41]. Immobility time was detected by a strain gauge in the Tail Suspension Chamber (Med Associates Inc., St. Albans, VT, USA). A duration of time in which the force of the mouse's movement did not exceed a set threshold was counted as immobility time.

\subsubsection{Forced Swim Test}

The mice were put inside a cylinder filled with water for $6 \mathrm{~min}$. The movement of the animal was recorded and analyzed using ForcedSwimScan (Cleversys, Reston, VA, USA). Floating time (during which the animal remained almost immobile and with its head above water) was used as a parameter to indicate depression-like behavior.

\subsection{Immunohistochemical Staining}

Animals were anaesthetized at 1, 7 and 120 day(s) post-irradiation. After perfusion with $4 \%$ paraformaldehyde, brain tissues were dissected, postfixed and then kept in 30\% sucrose in $0.1 \mathrm{M}$ phosphate buffer (pH: 7.4). Sagittal brain sections were cut at $40 \mu \mathrm{m}$ and processed for Ki67, NeuN and doublecortin (DCX) immunohistochemistry in free floating sections. After treatment with $3 \% \mathrm{H}_{2} \mathrm{O}_{2}$ and blocking with serum, free-floating sections were incubated with antibodies against DCX (1:500; Santa Cruz Biotechnology Inc., Santa Cruz, CA, USA), NeuN (1:500; Gene Tex, Hsinchu City, Taiwan), and Ki 67 (1:400; Gene Tex, Hsinchu City, Taiwan) overnight. The sections were then washed and incubated with respective secondary antibodies followed by avidin-biotin complex (ABC) reagent (Vector Laboratories Inc., Burlingame, CA, USA). After reaction in DAB Peroxidase Substrate (Vector Laboratories Inc., Burlingame, CA, USA), the sections were washed, mounted, counterstained and covered. The slides were examined and photographed under microscopy (Leica Microsystems GmbH, Wetzlar, Germany). The Stereologer System (Stereology Resource Center, Biosciences Inc. Tampa, FL, USA) was used to unbiasedly analyze the number of DCX and Ki67 immunopositive cells in the subgranular zone, and indicated the number/volume of the hilus of the dentate gyrus $\left(\mathrm{mm}^{3}\right)$.

\subsection{RNA Extraction from the Mouse Brain}

RNA extraction from brain samples was performed using the miRNeasy Mini Kit (Qiagen, Hilden, Germany). The cerebrum was homogenized, and RNA extraction was performed according to the manufacturer's instructions. RNA concentration and integrity were checked using the Nanodrop and Bioanalyzer system (Agilent Technologies, Santa Clara, CA, USA) before being subjected to miR sequencing and qPCR analysis.

\subsection{Systematic miR Sequencing (miRSeq) Analysis}

miRSeq was carried out using CAP-miRSeq (Molecular Genomics Pte Ltd., Singapore). The detected miRs were further compared between the control and irradiated animals and summarized using a heatmap. 


\subsection{Real-Time Quantitative Reverse Transcription PCR (qRT-PCR) Analysis of miR}

RNA was first reversely transcribed using the miScript II RT kit (Qiagen, Hilden, Germany). The $20 \mu \mathrm{L}$ reaction mixture, including $4 \mu \mathrm{L} 5 \times$ HiSpec buffer, $2 \mu \mathrm{L} 10 \times$ nucleotide mix, $2 \mu \mathrm{L}$ reverse transcripts mix, $5 \mu \mathrm{L}$ template RNA and $7 \mu \mathrm{L}$ nuclease-free water, was incubated at $37^{\circ} \mathrm{C}$ for $1 \mathrm{~h}$ followed by $95^{\circ} \mathrm{C}$ for $5 \mathrm{~min}$. The resulting cDNA was then diluted by adding $80 \mu \mathrm{L}$ of nuclease-free water and stored at $-80^{\circ} \mathrm{C}$.

Twenty microliters of master mix, for real time PCR, was prepared as follows: $2 \mu \mathrm{L}$ diluted cDNA, $10 \mu \mathrm{L} 2 \times$ miScript SYBR green PCR master mix, $2 \mu \mathrm{L} 10 \times$ miScript universal primer and $2 \mu \mathrm{L}$ primer for target miR, and $4 \mu \mathrm{L}$ nuclease-free water. Samples were denatured at $95^{\circ} \mathrm{C}$ for $15 \mathrm{~min}$, followed by 40 cycles of denaturation at $94{ }^{\circ} \mathrm{C}$ for $15 \mathrm{sec}$, annealing at $55^{\circ} \mathrm{C}$ for $30 \mathrm{sec}$, and extension at $70{ }^{\circ} \mathrm{C}$ for $30 \mathrm{~s}$ PCR amplification was carried out in QuantStudio 6 Real-Time PCR Systems (Thermo Fisher Scientific, Waltham, MA, USA). Fluorescence data were then collected. The average expression of miR-68 and miR-64 was used as internal control.

\subsection{Predication of miR-34a-5p Targets and Luciferase Reporter Assay}

Several online databases (TargetScan, miRanda, TarBase, miR2Disease, miRTarBase, miRecords, miRWalk) were used to analyze and predict the potential target genes of miR$34 a-5 p$, one of the miRs that shows significant changes after irradiation. Tia1, one of the miR-34a-5p targets, was selected to further validate their direct interaction because down-regulation of Tia 1 increases inflammatory response and chronic stress, which may prevent neurogenesis [42-45]. The luciferase reporter assay was based on the previous description [46]. The fragments of $3^{\prime}$ UTR of mouse Tia1 containing the binding sequence of miR34a-5p were amplified by RT-PCR. The primers used were 5'-CAC GAT GGT GGA TGT TTG CC- $3^{\prime}$ and $5^{\prime}$-GAT GCG GCG AGG ACT TAT CA-3'. The amplified fragments were directionally cloned into the PmeI and XhoI unique restriction enzyme sites of psiCHECK-2 plasmid (C8021, Promega Corporation, Madison, WI, USA), which are downstream of the Renilla luciferase gene. Transfection efficiency was normalized using firefly luciferase. The miR-34a-5p seed region of Tia1 was mutated using the Phusion Site-Directed Mutagenesis Kit (Thermo Fisher Scientific, Waltham, MA, USA) with primer sequences of 5'-phosphate ATT CCT TTT TTA AAA ATA AGA GGC-3' and 5'-phosphate GTC AAT CCC TGC ATT TGT CTT TG. HEK293T cells were co-transfected with $0.2 \mu \mathrm{g}$ psiCHECK-2 constructed with 3'UTR binding sites of miR-34a-5p and $100 \mathrm{nM}$ miR-34a$5 p$ mimic (Dharmacon, Lafayette, CO, USA) or scrambled mimic control (Dharmacon, Lafayette, CO, USA), using X-tremeGENE siRNA Transfection Reagent (Roche, Basel, Switzerland) according to the manufacturer' s protocol. The Dual-Luciferase ${ }^{\circledR}$ Reporter Assay System (Promega Corporation, Madison, WI, USA) was used to measure luciferase and renilla signals $48 \mathrm{~h}$ after transfection.

\section{8. $q R T-P C R$ Analysis of Tia1 $m R N A$}

The RNA was reversely transcribed using Maxima first strand cDNA synthesis kits (Thermo Fisher Scientific, Waltham, MA, USA). One microgram of RNA was added to $4 \mu \mathrm{L}$ $5 \times$ Reaction Mix and $2 \mu \mathrm{L}$ Maxima Enzyme Mix, and topped up to $20 \mu \mathrm{L}$ with nuclease-free water. Tubes were incubated at $25^{\circ} \mathrm{C}$ for $10 \mathrm{~min}$, followed by $50{ }^{\circ} \mathrm{C}$ for $45 \mathrm{~min}$ and $85^{\circ} \mathrm{C}$ for $5 \mathrm{~min}$. The resulting cDNA was then diluted by adding $100 \mu \mathrm{L}$ of nuclease-free water and stored in aliquots at $-20^{\circ} \mathrm{C}$.

Twenty microliters of master mix, for real time PCR, were prepared as follows: $2 \mu \mathrm{L}$ diluted cDNA, $10 \mu \mathrm{L} 2 \times$ Maxima SYBR Green qPCR Master Mix, $2 \mu \mathrm{L} 10 \times$ forward and reverse primers for target genes, and $4 \mu \mathrm{L}$ nuclease-free water. The primers were used for Tia1: 5' -GAGAAGGGCTATTCGTTT- ${ }^{\prime}$ and 5'-CCATACTGTTGTGGGTTT-3'; GAPDH: $5^{\prime}$ -GCACCGTCAAGGCTGAGAAC- $3^{\prime}$ and $5^{\prime}$-TGGTGAAGACGCCAGTGGA-3'. Samples were denatured at $95^{\circ} \mathrm{C}$ for $10 \mathrm{~min}$, followed by 40 cycles of: denaturation at $95{ }^{\circ} \mathrm{C}$ for $15 \mathrm{sec}$, annealing at $60^{\circ} \mathrm{C}$ for $30 \mathrm{sec}$, extension at $72{ }^{\circ} \mathrm{C}$ for $30 \mathrm{~s}$ PCR amplification was carried out in QuantStudio 6 Real-Time PCR Systems (Thermo Fisher Scientific, Waltham, 
MA, USA). Fluorescence data were then collected. The expression of GAPDH was used as the internal control.

\subsection{Western Blot}

The mouse cerebrum was homogenized in CelLytic MT Mammalian Tissue Lysis/Extraction Reagent (Sigma-Aldrich Corporation, St. Louis, MO, USA) containing $100 \mathrm{X} \mathrm{Halt}^{\mathrm{TM}}$ Protease and Phosphatase Inhibitor Cocktail (Thermo Fisher Scientific, Waltham, MA, USA). The lysate was centrifuged at $15,000 \times g$ for $15 \mathrm{~min}$, and the supernatant was transferred into a clear Eppendorf tube. Pierce ${ }^{\mathrm{TM}}$ BCA Protein Assay Kit (Thermo Fisher Scientific, Waltham, MA, USA) was used to measure protein concentration.

Protein samples were separated by $10 \%$ SDS-PAGE, and then transferred to a nitrocellulose membrane. The membrane was blocked by Blotting One (Nacalai Tesque Inc., Kyoto, Japan), incubated with the respective primary antibodies ( $\beta$-actin, 1:1000, Cell Signalling Technology, Beverly, MA, USA; Tia1, 1:1000, Invitrogen, Thermo Fisher Scientific, Waltham, MA, USA) overnight at $4{ }^{\circ} \mathrm{C}$ followed by HRP-conjugated secondary antibodies $(1: 10,000$ dilution) at room temperature for $1 \mathrm{~h}$. The WesternBright Sirius Chemiluminescent Detection Kit (Advansta Inc, San Jose, CA, USA) was used to detect immunoreactive proteins. Membranes were then visualized and quantified using the Bio-Rad Gel Doc system. Band densities were measured by ImageJ and normalized by the respective loading control $\beta$-actin. The fold change relative to the control was calculated.

\subsection{Culture of Neural Stem Cells}

Mouse cortical neural stem cells (NSCs) were purchased from R\&D Systems, Inc. (Minneapolis, MN, USA). Cell culture flasks or plates were pre-coated with matrigel (Gibco, Thermo Fisher Scientific, Waltham, MA, USA). Cells were grown in NeuroCult ${ }^{\mathrm{TM}}$ basal medium (STEMCELL Technologies Singapore Pte Ltd., Singapore), and supplemented with NeuroCult ${ }^{\mathrm{TM}}$ proliferation supplement (STEMCELL Technologies Singapore Pte Ltd., Singapore), epidermal growth factor (EGF) and basic fibroblast growth factor (bFGF) (Invitrogen, Thermo Fisher Scientific, Waltham, MA, USA) in a humidified incubator at $37{ }^{\circ} \mathrm{C}$ with $5 \% \mathrm{CO}_{2}$. Cells were passaged using accutase (Gibco, Thermo Fisher Scientific, Waltham, MA, USA).

\subsection{RNA Isolation from NSCs and $q R T-P C R$ Analysis for miR and $m R N A$}

Cells were seeded in a matrigel-coated 6-well plate. RNA isolation and qRT-PCR analysis for miR and mRNA were performed as mentioned above.

\subsection{Western Blot for NSCs}

Cells were harvested in CelLytic MT Mammalian Tissue Lysis/Extraction Reagent (Sigma-Aldrich Corporation, St. Louis, MO, USA) containing $100 \times$ Halt $^{\text {TM }}$ Protease and Phosphatase Inhibitor Cocktail (Thermo Fisher Scientific, Waltham, MA, USA), and lysed by violent vortex several times before incubating on ice for $20 \mathrm{~min}$ on a shaker. After centrifugation at $15,000 \times g$ for $15 \mathrm{~min}$, the supernatant was transferred into a clear Eppendorf tube. The protein concentration was measured and samples were separated as described above.

\subsection{Overexpression of Tia1 in NSCs}

Mammalian vector pCMV6-AC-GFP, containing Tia1 (NM_009383) Mouse Tagged ORF Clone (No: MG226372, OriGene Technologies, Inc., Rockville, MD, USA) or blank control pCMV6-AC-GFP with C-terminal tGFP tag (No: PS100010, OriGene Technologies, Inc., Rockville, MD, USA), was transfected into NSCs using Lipofectamine 3000 reagent (Thermo Fisher Scientific, Waltham, MA, USA) according to the manufacturer' s instructions. 


\subsection{Statistical Analysis}

Data were expressed as mean \pm SEM, and $p<0.05$ was considered as statistically significant. The Student's t-test was used to compare two sets of quantitative data. For the comparison among three or more groups, one-way analysis of variance (ANOVA) was used followed by Bonferroni-corrected pairwise post-hoc tests.

\section{Results}

\section{1. $\gamma$-Irradiation at P3 Induced Depression-Like Behavior in Adult Mice}

The open-field test showed no difference in distance travelled between non-irradiated and irradiated mice (Figure 1A). Irradiated mice displayed a significantly increased time of immobilization in the tail suspension test (Figure 1B) and the forced swim test (Figure 1C) compared to the control, suggesting that $\gamma$-irradiation-induced depression-like behavior in adult mice.

A

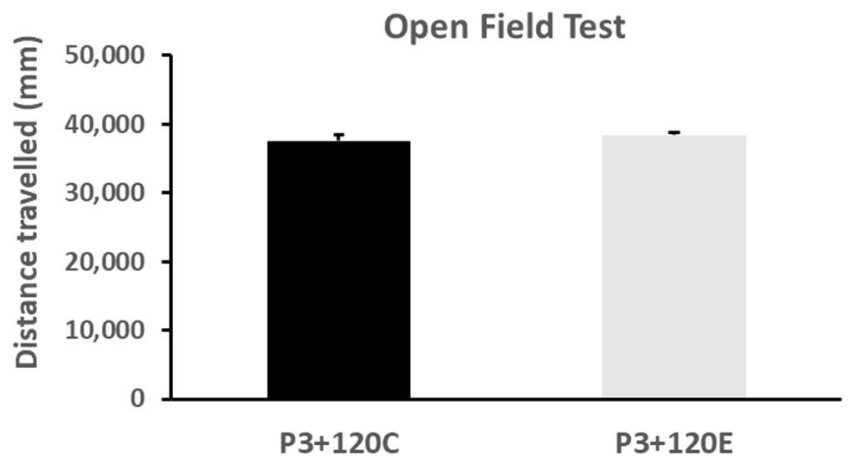

B

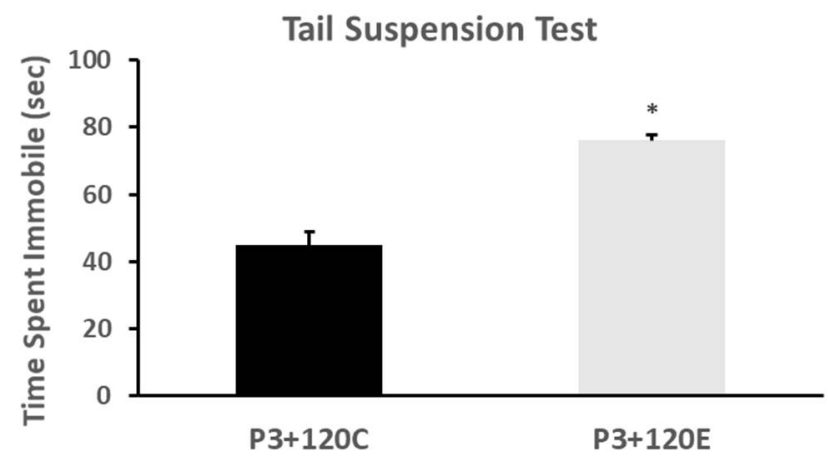

C

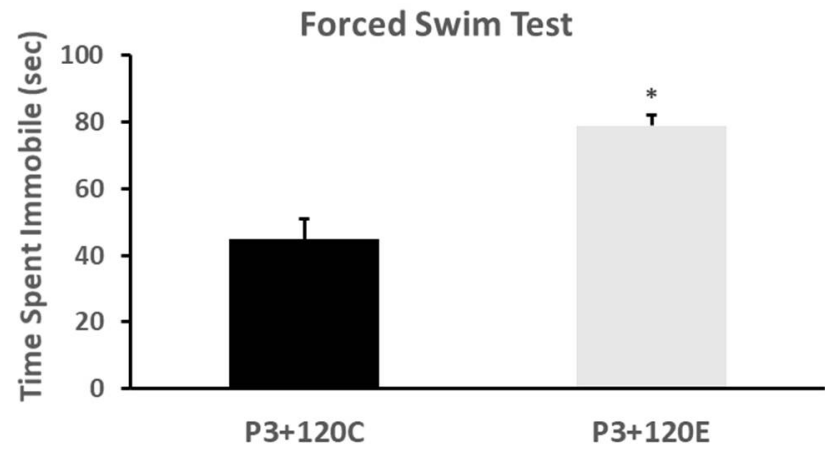

Figure 1. $\gamma$-irradiation with 5Gy at postnatal day 3 (P3) induced depression-like behavior in adult mice without locomotor activity change. (A) The total distance travelled in the open field (locomotor) test; (B) the immobile time in the tail suspension test; (C) the immobile time in the forced swim test. Data are expressed as mean \pm SEM, and analyzed by Student's $t$-test $(n=12) .{ }^{*} p<0.05$ vs. P3+120C. 
3.2. $\gamma$-Irradiation with 5Gy Induced Hypoplasia of The Infrapyramidal Blade of The Stratum Granulosum, and Aberrant and Impaired Neurogenesis in the Subgranular Zone of the Dentate Gyrus

NeuN immunohistochemistry revealed hypoplasia of the infrapyramidal blade of the stratum granulosum of the dentate gyrus, which appeared at 1 day (Figure 2A,B) after irradiation at P3, and persisted from 7 (Figure 2C,D) to 120 days (Figure 2E,F) after irradiation. In the suprapyramidal blade of the stratum granulosum of the dentate gyrus, the loss of NeuN immunopositive neurons also occurred (Figure 2 B,D,F), particularly at 120 days after irradiation (Figure 2F), compared to the age-matched control (Figure 2A,C,E).
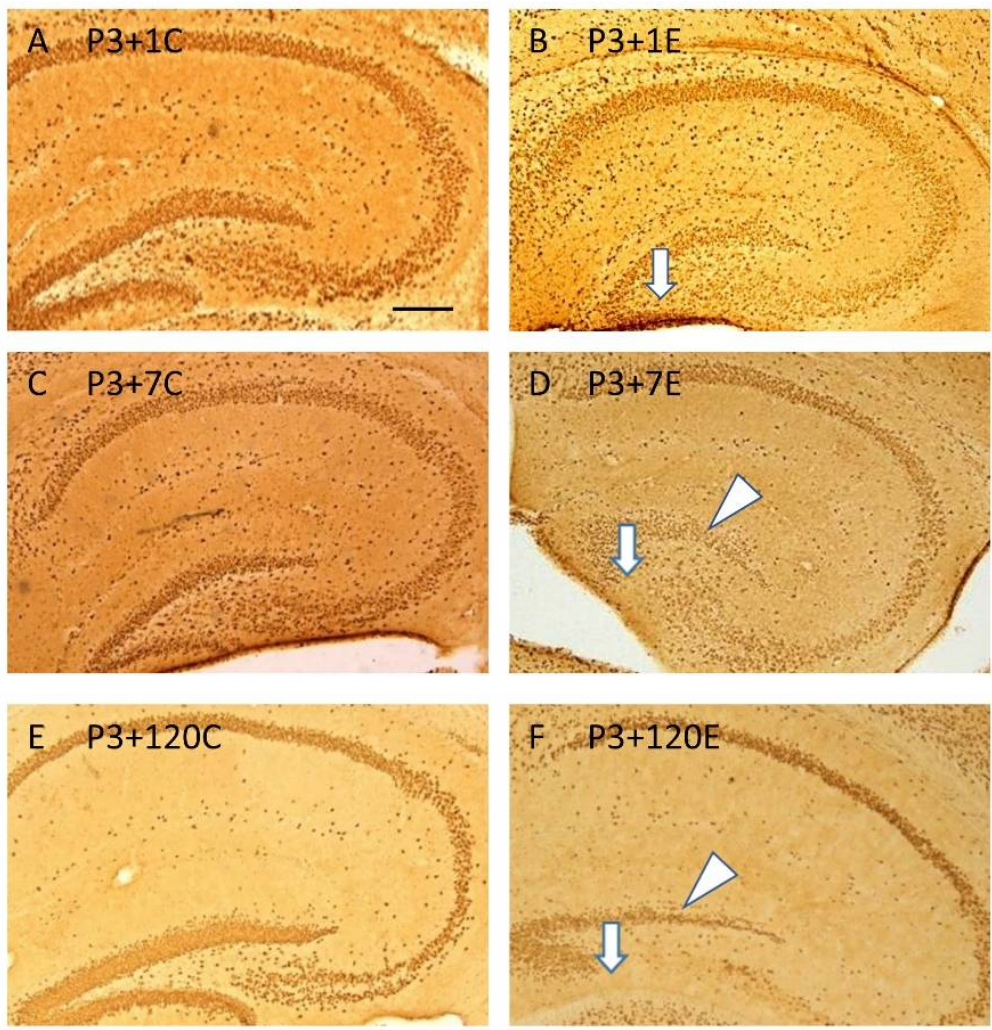

Figure 2. NeuN immunostaining shows that $\gamma$-irradiation with $5 \mathrm{~Gy}$ at postnatal day 3 induced hypoplasia of the infrapyramidal blade of the stratum granulosum of the dentate gyrus (arrows) at 1 ((B) compared to (A) in the control), 7 ((D) compared to (C) in the control), and 120 ((F) compared to $€$ in the control) days after radiation exposure. Loss of NeuN immunopositive neurons also occurred in the suprapyramidal blade of the stratum granulosum of the dentate gyrus, particularly at 7 (arrowhead in (D)) and 120 (arrowhead in (D)) days after irradiation when compared to the age-matched control mice $(\mathbf{C}, \mathbf{E})(n=5)$. Scale bar $=200 \mu \mathrm{m}$ in A applies to $(\mathbf{B}-\mathbf{F})$.

Ki67 immunohistochemistry indicated a significant reduction in Ki67 immunopositive cells in the hilus, including the subgranular zone of the dentate gyrus, which started at 1 day (Figure 3A-D,I) after irradiation of P3 mice, and persisted from 7 days (Figure $3 \mathrm{E}, \mathrm{F}$ and I) to 120 days (Figure 3G-I) after irradiation exposure. Counterstaining with hematoxyin showed many apoptotic bodies in the hilus (including the subgranular zone) of the dentate gyrus at 1 day after irradiation (Figure 3D). At 120 days after irradiation, aberrant Ki67 immunopositive dividing cells were observed in the molecular layer of the dentate gyrus (Figure 3H). 

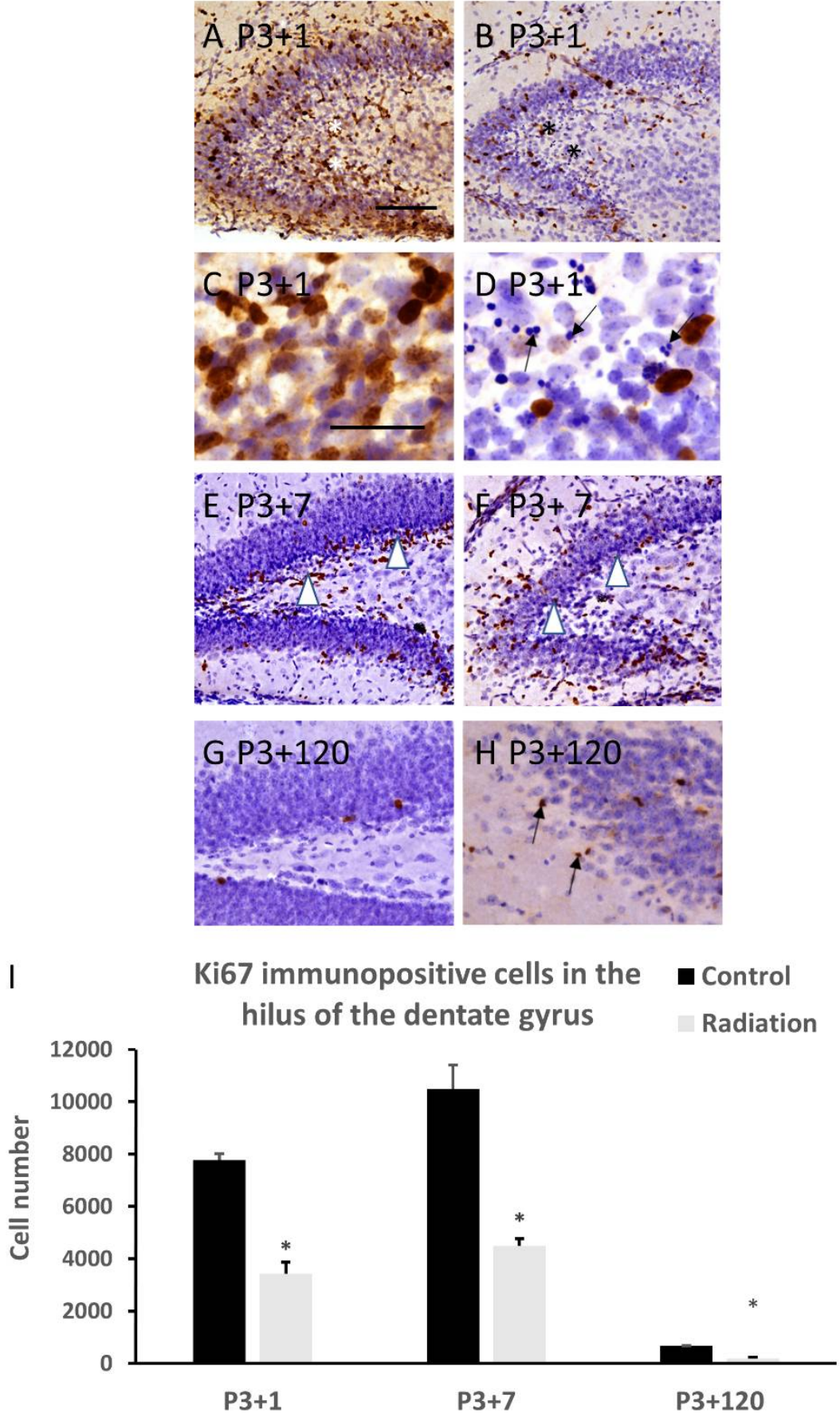

Figure 3. Ki67 immunostaining shows that $\gamma$-irradiation with $5 \mathrm{~Gy}$ at postnatal day 3 induced a significant reduction in Ki67 immunopositive cells in the hilus of the dentate gyrus, including the subgranular zone (asterisks), at 1 (B,D compared to (A), (C) in the control, (C,D) are magnified figures from (A,B), respectively, (I)) (arrows in (D) indicate apoptotic bodies), 7 (F compared to (E) in the control, white arrowheads indicate Ki67 immunopositive cells, (I)), and $120((\mathbf{H})$ compared to (G) in the control, I) days after radiation exposure. Aberrant Ki67 immunopositive cells appeared in the molecular layer of the dentate gyrus at 120 days after radiation exposure (arrow in $(\mathbf{H}))(n=5)$. ${ }^{*} p<0.05$ vs. respective control. Scale bar $=100 \mu \mathrm{m}$ in $(\mathbf{A})$ applies to $(\mathbf{B}, \mathbf{E}-\mathbf{H})$. Scale bar $=50 \mu \mathrm{m}$ in C applies to (D).

DCX immunohistochemistry showed a homogenous distribution of DCX in the dentate gyrus at postnatal day $4(\mathrm{P} 3+1)$ (Figure 4A) and day $10(\mathrm{P} 3+7)$ (Figure 4C) in the control (Figure 4A,C) and experimental (Figure 4B,D) mice. In the experimental mice (Figure 4B,D), 
DCX immunostaining in the entire dentate gyrus was weaker than in the control mice (Figure $4 \mathrm{~A}, \mathrm{C}$ ), particularly in the subgranular zone at 7 days after irradiation (Figure 4D compared to Figure 4C). At 120 days after irradiation, the number of DCX immunopositive cells in the subgranular zone of the dentate gyrus was significantly reduced in the irradiated mice (Figure $4 \mathrm{~F}, \mathrm{H}, \mathrm{I}$ ) compared to the control (Figure $4 \mathrm{E}, \mathrm{G}$ ). Furthermore, aberrant newly generated DCX immunopositive cells were observed in the molecular layer of the dentate gyrus (Figure 4F,H).
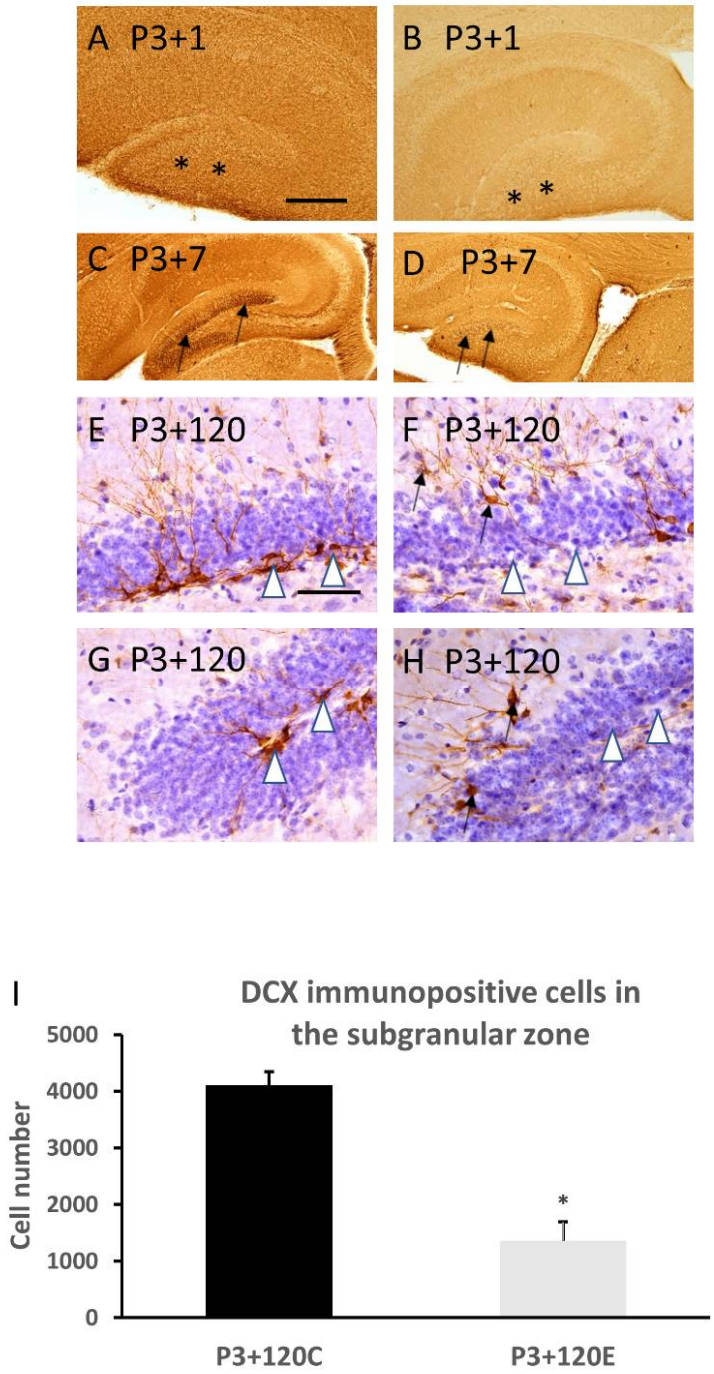

Figure 4. DCX immunostaining shows that $\gamma$-irradiation with 5Gy at postnatal day 3 induced an obvious reduction in DCX immunopositive product in the dentate gyrus at 1 day $((\mathbf{B})$ compared to (A) in the control, asterisks) and 7 days ((D) compared to (C) in the control, in particular in the subgranular zone, arrows indicate DCX immunopositive cells). Quantitative study indicates a significant reduction in DCX immunopositive neurons in the subgranular zone of the dentate gyrus at 120 days after radiation exposure (white arrowheads in $(\mathbf{F}),(\mathbf{H})$ indicate subgranular zone with fewer DCX immunopositive cells compared to those in $(\mathbf{E}, \mathrm{G})$ which indicate more DCX immunopositive cells. (I)). Aberrant DCX immunopositive neurons also appeared in the molecular layer of the dentate gyrus at 120 days after radiation exposure (arrows in $(\mathbf{F}, \mathbf{H}))(n=5) .{ }^{*} p<0.05$ vs $\mathbf{P} 3+120 \mathrm{C}$. Scale bar $=200 \mu \mathrm{m}$ in (A) applies to (B-D). Scale bar $=100 \mu \mathrm{m}$ in E applies to $(\mathbf{F}-\mathbf{H})$. 


\subsection{Systematic miRSeq and Real Time RT-PCR}

A total of $771 \mathrm{miRs}$ was detected and analyzed. Seven miRs with significant changes between control and irradiated mice at $\mathrm{P} 3+1$ and $\mathrm{P} 3+7$ groups were summarized by the heatmap (Figure 5A). Statistical analysis indicated upregulation of miR-34a-5p at 1 and 7 day(s), but not 120 days after irradiation (Figure 5B). qRT-PCR further validated miRSeq and showed a significantly increased expression of miR-34a-5p in the mouse brain at 1 and 7 day(s) after irradiation (Figure 5C).

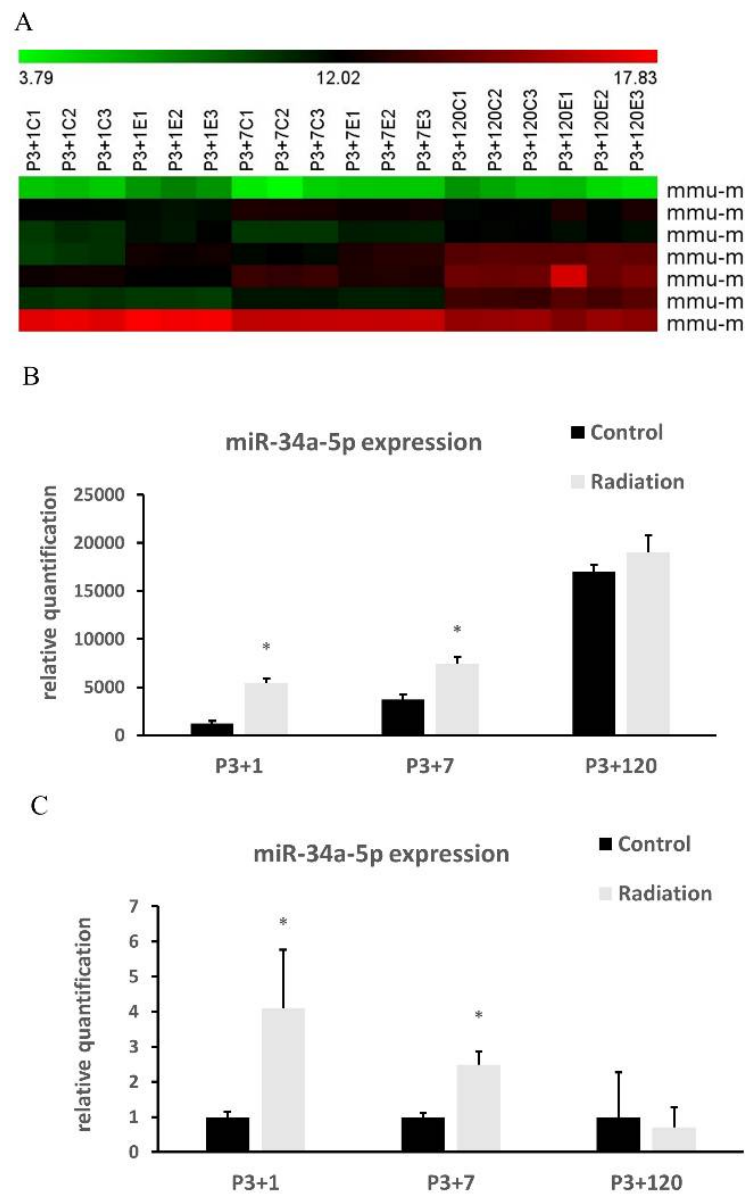

Figure 5. A heatmap displays seven differentially expressed miRNAs identified by systematic deep microRNA sequencing (miRSeq) among mice at 1, 7, 120 day(s) after irradiation at P3 and the respective control (A). The color bar from left to right represents the expression levels from low to high, and the number indicates the base- 2 logarithm of miR expression. Among these miRNAs, the expression of miR-34a-5p is summarized in (B). Real-Time Quantitative Reverse Transcription PCR (qRT-PCR) validates the increased expression of miR-34a-5p at 1 and 7 day(s) after radiation exposure (C). Data are expressed as mean $\pm \operatorname{SEM}(n=3) .{ }^{*} p<0.05$ vs respective control.

\section{4. miR-34a-5p Targeted on mRNA of Tia1}

The binding site of mouse miR-34a-5p exists in the position 269 to 275 of Tia1 $3^{\prime}$ UTR (Figure 6A), and their direct interaction, was confirmed by luciferase reporter assay (Figure 6B).

No change in luciferase activity was observed when the miR-negative control (miR$\mathrm{NC}$ ) or miR-34a-5p mimic was transfected into the blank plasmid psiCHECK-2 (Figure 6B). However, when miR-34a-5p mimic was co-transfected with psiCHECK-2 containing mouse Tia1 3' -UTR binding sequence into HEK 293 cells, the luciferase intensity was reduced significantly compared to the negative control (Figure 6B), indicating the binding of the miR-34a-5p and $3^{\prime}$-UTR regions of Tia1. miR-34a-5p did not bind to the mutant Tia1 $3^{\prime}$-UTR sites (Figure $6 \mathrm{~B}$ ), suggesting that Tia1 may function as the direct target of miR-34a-5p. 
A

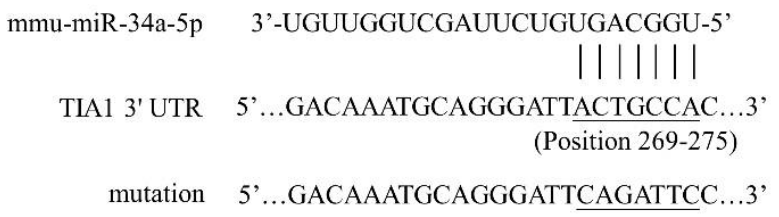

B

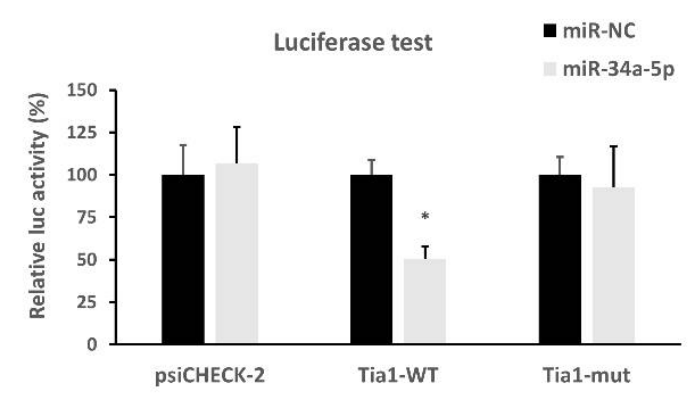

Figure 6. Direction interaction of miR-34a-5p with Tia1 examined by luciferase reporter assay. (A) Sequence alignment of putative miR-34a-5p binding sites in Tia1 $3^{\prime}$ UTRs, and the mutation sequences. (B) Activity of luciferase gene linked to the 3' UTR of Tia1 mRNA. HEK293T cells were co-transfected with psiCHECK-2 constructed with $3^{\prime}$ UTR binding sites of miR-34a-5p and miR$34 a-5 p$ mimic or scrambled mimic control. Luciferase and renilla signals were measured $48 \mathrm{~h}$ after transfection. Data are expressed as mean \pm SEM. ${ }^{*} p<0.05$.

\section{5. mRNA and Protein Expression of Tia1 in Mice Brain after $\Gamma$-Irradiation with 5Gy}

Tia1 mRNA decreased significantly at 1 and 120 day(s), but not at 7 days, after $\gamma$ irradiation with 5Gy compared to the respective controls (Figure 7A). A significant decrease in Tia1 protein occurred at 1 day (Figure 7B,C), but not 7 or 120 days (Figure 7B,C), after $\gamma$-irradiation.

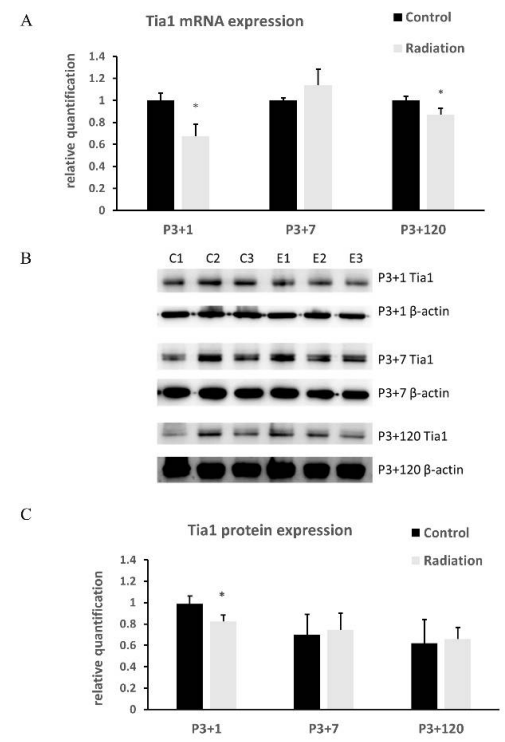

Figure 7. The expression of Tia1 in animal brains. Balb/c mice were $\gamma$-irradiated with 5Gy at P3, and brain samples were collected at 1, 7, and 120 day(s) after irradiation. (A) mRNA expression of Tia1 by qRT-PCR; (B) western blot images of Tia1; (C) statistical results of Tia1 protein levels. Data are expressed as mean $\pm \operatorname{SEM}(n=3) .{ }^{*} p<0.05$ vs respective control. 
3.6. $\Gamma$-Irradiation Increased the Expression of miR-34a-5p in NSCs and Decreased the mRNA Expression of Tia1

qRT-PCR indicated the increased expression of miR-34a-5p (Figure 8A) and decreased Tia1 miRNA (Figure 8B) in NSCs from 4 to $8 \mathrm{~h}$, but not at $1 \mathrm{~h}$ after $\gamma$-irradiation with $5 \mathrm{~Gy}$. This negative correlation between the expression of miR and its target mRNA further confirms that Tia1 is a direct target of miR-34a-5p.

\section{7. Г-Irradiation Dose- and Time-Dependently Decreased Protein Expression of Tia1 in NSCs}

NSCs were $\gamma$-irradiated with different doses from 0.2 to 5Gy. Western blot results showed that the $\gamma$-irradiation dose-dependently decreased the protein levels of Tia1 in NSCs (Figure 8C). When NSCs were $\gamma$-irradiated with 5 Gy, the reduction in Tia1 protein levels was time-dependent (Figure 8D).
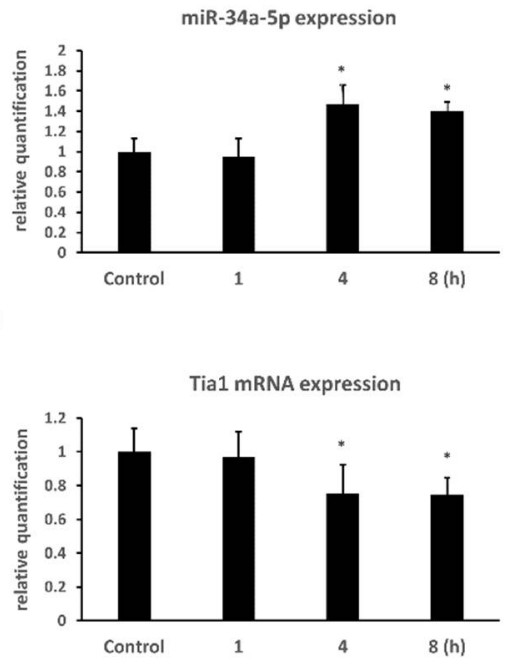

$\mathrm{C}$

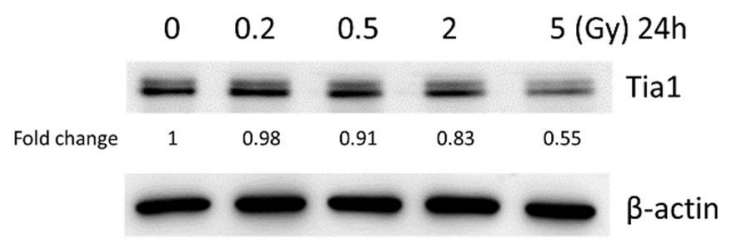

$\mathrm{D}$

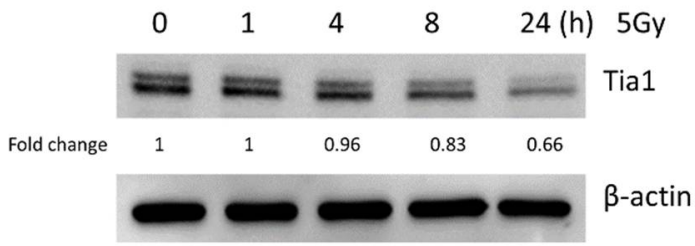

Figure 8. The expression of miR-34a-5p and Tia1 in NSCs after $\gamma$-irradiation. Time-dependent change of miR-34a-5p (A) and Tia1 (B) mRNA expression in NSCs after $\gamma$-irradiation with 5Gy. Data are expressed as mean \pm SEM $(\mathrm{n}=3)$. ${ }^{*} p<0.05$ vs control. The protein expression of Tia1 in NSCs examined by western blot is dose- $(\mathbf{C})$ and time-dependent $(\mathbf{D})$ after $\gamma$-irradiation.

\subsection{Overexpression of Tia1 Partially Blocked Г-Irradiation-Induced Impairment of Neurogenesis}

$\Gamma$-irradiation significantly decreased cell proliferation in NSCs transfected with either blank or Tia1 plasmid when compared with the respective non-irradiated groups (Figure 9A). The transfection of Tia1 plasmid partially blocked the loss of proliferating cells induced by $\gamma$-irradiation in NSCs (Figure 9A). The overexpression of Tia1 also enhanced cell proliferation in the non-irradiated groups as compared to NSCs transfected with blank plasmid (Figure 9A).

Western blotting showed that the transfection of Tia1 into NSCs enhanced the Tia1 protein levels compared to the blank plasmid group (Figure 9B). $\gamma$-irradiation with 5Gy reduced the Tia1 protein levels in NSCs transfected with blank plasmid, while this decrease was reversed by the transfection of Tia1 plasmid (Figure 9B), suggesting that promoting Tia1 expression in brain neurogenesis niches may be a novel therapeutic approach to prevent the radiation-induced impairment of neurogenesis. 

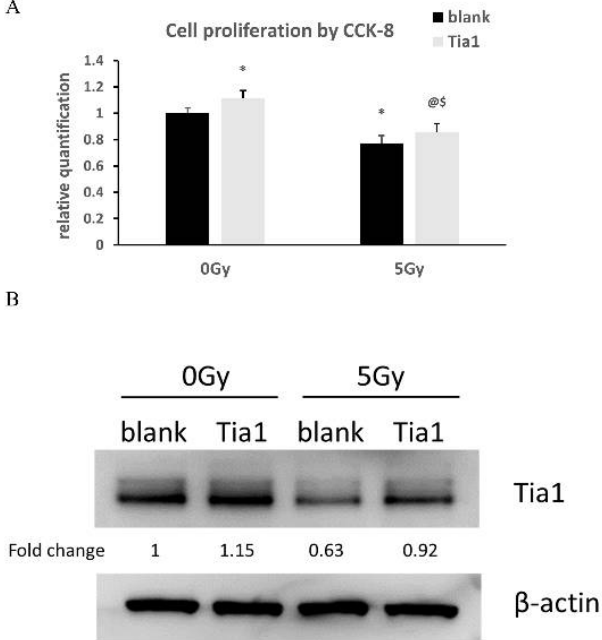

Figure 9. Effects of overexpression of Tia1 in NSCs after $\gamma$-irradiation. pCMV6-AC-GFP containing Tia1 or blank control was transfected into NSCs, which were then $\gamma$-irradiated with 5Gy or not irradiated as a control. (A) Cell proliferation in transfected NSCs. Data are expressed as mean \pm SEM $(n=5) .{ }^{*} p<0.05$ vs blank 0 Gy; @ $p<0.05$ vs. Tia1 0 Gy; $\$ p<0.05$ vs. blank 5 Gy. (B) Protein expression of Tia1 in transfected NSCs examined by western blot.

\section{Discussion}

\subsection{Radiation, Hippocampal Neuropathology and Depression}

Survivors of major nuclear accidents or war may experience brain damage and depression $[1,2,47,48]$. In Chernobyl clean-up workers and liquidators with depression, the radiation-induced dysfunction of the cortico-limbic system in the left dominant hemisphere of the brain, with a specific involvement of the hippocampus, is considered to be the key cerebral basis of post-radiation brain damage $[1,2,47,48]$. Patients with depressive symptoms have smaller dentate gyrus [5]. This was supported by a recent study showing that early life adversity increased major depressive disorder (MDD) and suicide risk and could potentially affect the dentate gyrus, leading to a smaller dentate gyrus and fewer granular neurons in MDD [12]. In the present study, irradiation at P3 induced depression in adult animals. A neuropathological study showed that irradiation-induced hypoplasia of the infrapyramidal blade of the stratum granulosum of the dentate gyrus and neuronal loss occurred as early as one day after irradiation. At 120 days after irradiation, hypoplasia of the infrapyramidal blade of the stratum granulosum of the dentate gyrus persisted; meanwhile, aberrant cell division and neurogenesis in the molecular layer of the dentate gyrus were found. Our animal study strongly supports the conclusion from human data [12] and suggests that early life radiation-induced hypoplasia of the infrapyramidal blade of the stratum granulosum, as well as impairment and aberrant neurogenesis of the dentate gyrus, may be related to smaller dentate gyrus sizes and the development of depression. These pathological changes also support the neurogenesis and cellular plasticity hypotheses of depression. Radiation was shown to induce depression in mouse models [17-20]. However, previous studies on adult animals did not show hypoplasia of the infrapyramidal blade of the stratum granulosum of the dentate gyrus and aberrant cell division and neurogenesis. The pathological changes at 1 day after irradiation of P3 mice strongly suggest that therapeutic approaches to prevent early life adversity may impede the development of different neuropsychological disorders at the late stages of human life.

\section{2. $m i R-34 a-5 p$ in Neurogenesis and Depression}

Increased miR-34a was detected in the brain, blood and cerebrospinal fluids of patients or animals with depression [28]. Of the differentially expressed miRs in the present study, we chose to validate miR-34a-5p and investigate its target due to the fact that it negatively regulates neural stem cell proliferation, differentiation, neuronal migration and 
maturation [49-51]. Brain miR-34a-5p changes were also found to be involved in other brain insults [52]. Radiation-induced miR-34a-5p changes in the blood may be involved in the development of Alzheimer' s disease, depression and schizophrenia, suggesting that miR-34a-5p may be involved in the common brain neuropathological changes in these diseases, such as impairment of neurogenesis [28]. Altered miR-34a-5p in the cerebrospinal fluid and blood was considered as an early biomarker of major depression disorder [53] or Alzheimer's disease [54]. Plasma miR-34a-5p expression may be used to distinguish radiation exposure levels in mice [55]. Furthermore, miR-34a-5p contributes to synaptic plasticity via dis-inhibition of the translation of key plasticity-related molecules [56]. The upregulation of miR-34a-5p was revealed at 1 and 7 day(s) after irradiation at P3 in the present study. Radiation-induced upregulation of miR-34a-5p and reduced cell proliferation were further confirmed in a neural stem cell model. miR-34a is a tumor-suppressor gene and overexpression of miR-34a suppressed the expression of 136 neuronal progenitor genes [57]. The radiation-induced upregulation of brain miR-34a-5p in both animal and stem cell models may prevent brain neurogenesis, leading to hypoplasia of the infrapyramidal blade of the stratum granulosum, impairment of neurogenesis, aberrant cell division and neurogenesis in the molecular layer of the dentate gyrus, and subsequent depression.

\section{3. miR-34a-5p Targets Tia1 to Prevent Neurogenesis}

miR-34a targets E2F3, Numbl, platelet-derived growth factor receptor A (PDGFRA), synaptotagmin 1 (Syt1), autophagy-related 9a (Atg9a), CD44, cyclic AMP response-element binding protein (CREB), brain-derived neurotrophic factor (BDNF) to inhibit cell proliferation, migration, invasion and adhesion [58-65]. It regulates extracellular signalregulated kinase 1/2 (ERK) and p38, and increases nuclear factor kappa light chain enhancer of activated B cells (NF-kB), Sirtuin 1 (SIRT1) and Bcl2, to promote or reduce apoptosis [66-68]. The miR-34a- A central nucleotide-binding oligomerization domain (NOD)-, C-terminal leucine rich repeat domain $(L R R)-$ and caspase activation and recruitment domains (CARDs) -containing 5 (NLRC5)

-NFKB signaling pathway may be involved in HIV-1 Tat-mediated microglial inflammation [69]. miR-34a-5p suppresses tumorigenesis by targeting the Notch signalling pathway [70] or high mobility group AT-hook 2 (HMGA2) [71]. It inhibited proliferation, migration, and cell invasion, accompanied by targeting of matrix metalloproteinase 9 (MMP9) activity and the microtubule-associated protein 2 (MAP2) protein, to reduce their expression [63]. miR-34a-5p also inhibits N-methyl D-aspartate(NMDA) receptors, leading to neuroplasticity changes and Alzheimer's disease development [72]. Radiation-induced up-regulation of miR-34a-5p in the small intestine and peripheral blood down-regulated hippocampal BDNF, leading to the cognitive impairment [55]. In the present study, we chose Tia1 from many miR-34a-5p targets to confirm its gene and protein expression and validate its direct interaction with miR-34a-5p. This is because Tia 1 reduction increases detrimental inflammatory responses in different types of cells and tissues such as bone [44], endometrium [42], peritoneal macrophages [45], and the central nervous system during chronic stress [43]. It controls a large network of immune system genes with modulatory roles in synaptic plasticity and long-term memory, which may be involved in stress-related psychiatric conditions [73]. Tia1 mRNA is detectable in the mouse brain during embryogenesis [74], and is linked to the pathophysiology of neurodegeneration, e.g., Alzheimer' s disease [39]. Previous studies suggested that Tia1 acts as the target of several miRs, e.g., miR-19a, miR-487a and miR-599 [75-77]. In both animal and neural stem cell models, we confirmed that irradiation reduced Tia1 gene and protein expression. In the neural stem cell models, $\gamma$-irradiation dose- and time-dependently decreased cell proliferation in NSCs, accompanied by the increase in miR-34a-5p expression as well as the reduction in Tia1 mRNA and protein expression. The luciferase reporter assay indicated a direct interaction between miR-34a-5p and Tia1. The overexpression of Tia1 in NSCs partially reversed the decrease in cell proliferation induced by $\gamma$-irradiation, strongly suggesting the involvement of Tia1 in neurogenesis. Our results, therefore, suggest that the radiation-induced interaction of 
miR-34a-5p and Tia1 may increase inflammatory responses of neural stem cells, leading to the impairment of neurogenesis and the subsequent hypoplasia of the infrapyramidal blade of the stratum granulosum, and aberrant cell division and neurogenesis in the molecular layer of the dentate gyrus.

\section{Conclusions}

The present study showed that irradiation in P3 mice induced hypoplasia of the infrapyramidal blade of the stratum granulosum, and aberrant and impaired cell division and neurogenesis in the dentate gyrus. Hypoplasia of the infrapyramidal blade of the stratum granulosum and impairment of cell division and neurogenesis in the dentate gyrus may be related to the radiation-induced upregulation of miR-34a-5p and downregulation of its target gene Tia1. Our results may provide new clues for understanding the mechanism of the development of depression and for the development of novel therapeutic approaches to the prevention or treatment of depression.

Author Contributions: Conceptualization, F.R.T.; methodology, F.R.T., H.W., Z.M., H.S.; software, F.R.T., Z.M., P.W.; validation, H.W., Z.M., H.S., Z.W. and L.L.; formal analysis, F.R.T., H.W., Z.M., P.W.; investigation, H.W., Z.M., H.S., Z.W. and L.L.; resources, F.R.T.; data curation, H.W., F.R.T.; writingoriginal draft preparation, H.W., F.R.T.; writing - review and editing, F.R.T., G.S., B.R.; visualization, F.R.T., H.W., Z.M.; supervision, F.R.T.; project administration, F.R.T.; funding acquisition, F.R.T., G.S. All authors have read and agreed to the published version of the manuscript.

Funding: This research was funded by National Research Foundation of Singapore, grant number Block grant.

Institutional Review Board Statement: The study was conducted according to the guidelines of the Declaration of Helsinki, and approved by the Institutional Animal Care and Use Committee (IACUC), National University of Singapore (IACUC number: R15-1576, 22/04/2016).

Informed Consent Statement: Not applicable.

Data Availability Statement: The data presented in this study are available on request from the corresponding author. The data are not publicly available due to ethical restrictions.

Acknowledgments: This study was supported by grants from the National Research Foundation of Singapore to the Singapore Nuclear Research and Safety Initiative (F.T., G.S.) and the behavioral experiments were carried out at the Neuroscience Phenotyping Core Facility, which is supported by the NMRC NUHS Centre Grant-Neuroscience Phenotyping Core (NMRC/CG/M009/2017_NUH/NUHS).

Conflicts of Interest: The authors declare no conflict of interest.

\section{Abbreviations}

ANOVA Analysis of variance

Atg9a Autophagy-related 9a

BDNF Brain-derived neurotrophic factor

bFGF Basic fibroblast growth factor

CREB Cyclic AMP response-element binding protein

DCX Doublecortin

EGF Epidermal growth factor

ERK Extracellular signal-regulated kinase $\frac{1}{2}$

HEK Human embryonic kidney

HMGA2 High Mobility Group AT-Hook 2)

MAP2 Activity and microtubule-associated protein 2

MDD Major depressive disorder

miR MicroRNA 


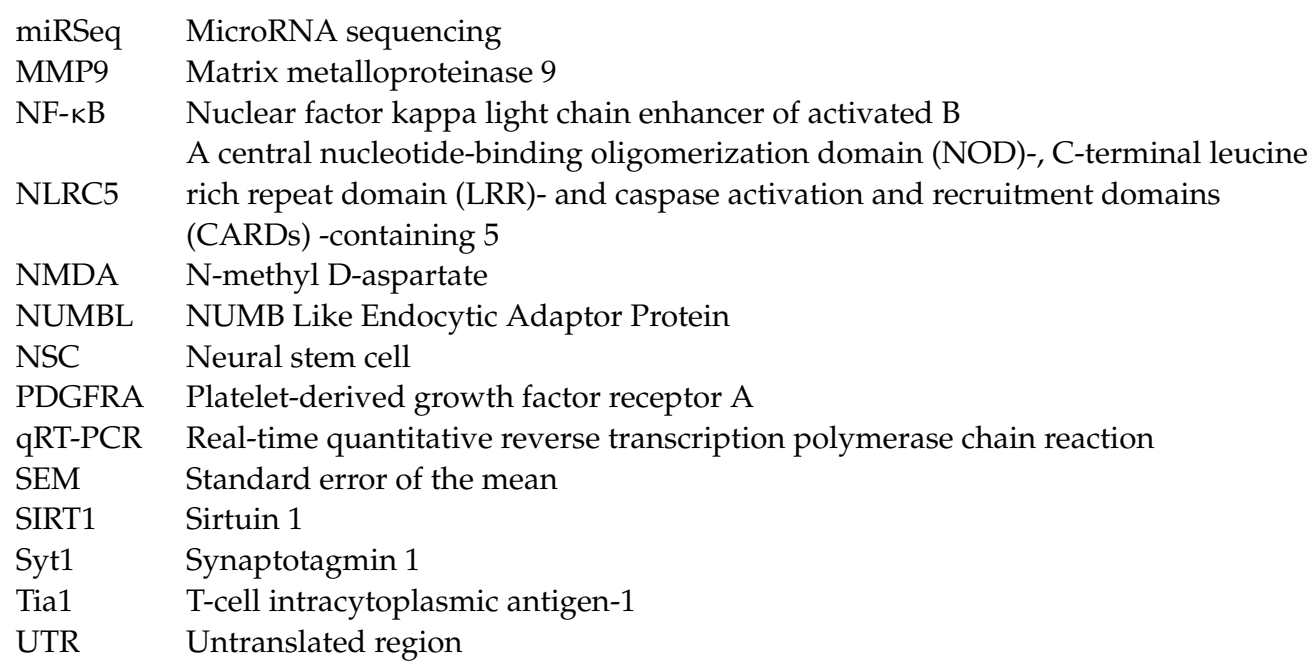

\section{References}

1. Loganovsky, K.N.; Vasilenko, Z.L. Depression and ionizing radiation. Probl. Radiatsiinoi Medytsyny Ta Radiobiolohii 2013, 18, 200-219.

2. Remennick, L.I. Immigrants from Chernobyl-affected areas in Israel: The link between health and social adjustment. Soc. Sci. Med. 2002, 54, 309-317. [CrossRef]

3. Loganovsky, K.N.; Loganovskaja, T.K.; Nechayev, S.Y.; Antipchuk, Y.Y.; Bomko, M.A. Disrupted development of the dominant hemisphere following prenatal irradiation. J. Neuropsychiatry. Clin. Neurosci. 2008, 20, 274-291. [CrossRef] [PubMed]

4. Contis, G.; Foley, T.P., Jr. Depression, suicide ideation, and thyroid tumors among ukrainian adolescents exposed as children to chernobyl radiation. J. Clin. Med. Res. 2015, 7, 332-338. [CrossRef] [PubMed]

5. Gold, S.M.; Kern, K.C.; O'Connor, M.F.; Montag, M.J.; Kim, A.; Yoo, Y.S.; Giesser, B.S.; Sicotte, N.L. Smaller cornu ammonis 2-3/dentate gyrus volumes and elevated cortisol in multiple sclerosis patients with depressive symptoms. Biol. Psychiatry 2010, 68, 553-559. [CrossRef] [PubMed]

6. Sapolsky, R.M. Why stress is bad for your brain. Science 1996, 273, 749-750. [CrossRef]

7. Satterthwaite, T.D.; Cook, P.A.; Bruce, S.E.; Conway, C.; Mikkelsen, E.; Satchell, E.; Vandekar, S.N.; Durbin, T.; Shinohara, R.T.; Sheline, Y.I. Dimensional depression severity in women with major depression and post-traumatic stress disorder correlates with fronto-amygdalar hypoconnectivty. Mol. Psychiatry. 2016, 21, 894-902. [CrossRef] [PubMed]

8. Sheline, Y.I.; Wang, P.W.; Gado, M.H.; Csernansky, J.G.; Vannier, M.W. Hippocampal atrophy in recurrent major depression. Proc. Natl. Acad. Sci. USA 1996, 93, 3908-3913. [CrossRef] [PubMed]

9. Sheline, Y.I. 3D MRI studies of neuroanatomic changes in unipolar major depression: The role of stress and medical comorbidity. Biol. Psychiatry 2000, 48, 791-800. [CrossRef]

10. Zheng, L.S.; Hitoshi, S.; Kaneko, N.; Takao, K.; Miyakawa, T.; Tanaka, Y.; Xia, H.; Kalinke, U.; Kudo, K.; Kanba, S.; et al. Mechanisms for interferon- $\alpha$-induced depression and neural stem cell dysfunction. Stem Cell Rep. 2014, 3, 73-84. [CrossRef]

11. Santarelli, L.; Saxe, M.; Gross, C.; Surget, A.; Battaglia, F.; Dulawa, S.; Weisstaub, N.; Lee, J.; Duman, R.; Arancio, O.; et al. Requirement of hippocampal neurogenesis for the behavioral effects of antidepressants. Science 2003, 301, 805-809. [CrossRef]

12. Boldrini, M.; Galfalvy, H.; Dwork, A.J.; Rosoklija, G.B.; Trencevska-Ivanovska, I.; Pavlovski, G.; Hen, R.; Arango, V.; Mann, J.J. Resilience Is Associated With Larger Dentate Gyrus, While Suicide Decedents With Major Depressive Disorder Have Fewer Granule Neurons. Biol. Psychiatry 2019, 85, 850-862. [CrossRef] [PubMed]

13. Jacobs, B.L.; van Praag, H.; Gage, F.H. Adult brain neurogenesis and psychiatry: A novel theory of depression. Mol. Psychiatry 2000, 5, 262-269. [CrossRef] [PubMed]

14. Kempermann, G.; Kronenberg, G. Depressed new neurons-Adult hippocampal neurogenesis and a cellular plasticity hypothesis of major depression. Biol. Psychiatry 2003, 54, 499-503. [CrossRef]

15. Vogel, G. Neuroscience. Depression drugs' powers may rest on new neurons. Science 2003, 301, 757. [CrossRef]

16. Warner-Schmidt, J.L.; Duman, R.S. Hippocampal neurogenesis: Opposing effects of stress and antidepressant treatment. Hippocampus 2006, 16, 239-249. [CrossRef]

17. Kang, J.; Kim, W.; Seo, H.; Kim, E.; Son, B.; Lee, S.; Park, G.; Jo, S.; Moon, C.; Youn, H.; et al. Radiation-induced overexpression of transthyretin inhibits retinol-mediated hippocampal neurogenesis. Sci. Rep. 2018, 8, 8394. [CrossRef]

18. Snyder, J.S.; Soumier, A.; Brewer, M.; Pickel, J.; Cameron, H.A. Adult hippocampal neurogenesis buffers stress responses and depressive behaviour. Nature 2011, 476, 458-461. [CrossRef]

19. Son, Y.; Yang, M.; Kim, J.S.; Kim, J.; Kim, S.H.; Kim, J.C.; Shin, T.; Wang, H.; Jo, S.K.; Jung, U.; et al. Hippocampal dysfunction during the chronic phase following a single exposure to cranial irradiation. Exp. Neurol. 2014, 254, 134-144. [CrossRef] [PubMed]

20. Son, Y.; Yang, M.; Wang, H.; Moon, C. Hippocampal dysfunctions caused by cranial irradiation: A review of the experimental evidence. Brain Behav. Immun. 2015, 45, 287-296. [CrossRef] [PubMed] 
21. Tang, F.R.; Loke, W.K.; Wong, P.; Khoo, B.C. Radioprotective effect of ursolic acid in radiation-induced impairment of neurogenesis, learning and memory in adolescent BALB/c mouse. Physiol. Behav. 2017, 175, 37-46. [CrossRef]

22. Guo, Y.R.; Liu, Z.W.; Peng, S.; Duan, M.Y.; Feng, J.W.; Wang, W.F.; Xu, Y.H.; Tang, X.; Zhang, X.Z.; Ren, B.X.; et al. The Neuroprotective Effect of Amitriptyline on Radiation-Induced Impairment of Hippocampal Neurogenesis. Dose-Response A Publ. Int. Hormesis Soc. 2019, 17, 1559325819895912. [CrossRef]

23. Wang, S.W.; Ren, B.X.; Qian, F.; Luo, X.Z.; Tang, X.; Peng, X.C.; Huang, J.R.; Tang, F.R. Radioprotective effect of epimedium on neurogenesis and cognition after acute radiation exposure. Neurosci. Res. 2019, 145, 46-53. [CrossRef] [PubMed]

24. Prabu, P.; Poongothai, S.; Shanthirani, C.S.; Anjana, R.M.; Mohan, V.; Balasubramanyam, M. Altered circulatory levels of miR-128, BDNF, cortisol and shortened telomeres in patients with type 2 diabetes and depression. Acta Diabetol. 2020, 57, $799-807$. [CrossRef] [PubMed]

25. Wingo, T.S.; Yang, J.; Fan, W.; Min Canon, S.; Gerasimov, E.S.; Lori, A.; Logsdon, B.; Yao, B.; Seyfried, N.T.; Lah, J.J.; et al. Brain microRNAs associated with late-life depressive symptoms are also associated with cognitive trajectory and dementia. NPJ Genom. Med. 2020, 5, 6. [CrossRef] [PubMed]

26. Zhang, H.P.; Liu, X.L.; Chen, J.J.; Cheng, K.; Bai, S.J.; Zheng, P.; Zhou, C.J.; Wang, W.; Wang, H.Y.; Zhong, L.M.; et al. Circulating microRNA 134 sheds light on the diagnosis of major depressive disorder. Transl. Psychiatry 2020, 10, 95. [CrossRef]

27. Maffioletti, E.; Cattaneo, A.; Rosso, G.; Maina, G.; Maj, C.; Gennarelli, M.; Tardito, D.; Bocchio-Chiavetto, L. Peripheral whole blood microRNA alterations in major depression and bipolar disorder. J. Affect. Disord. 2016, 200, 250-258. [CrossRef]

28. Segaran, R.C.; Chan, L.Y.; Wang, H.; Sethi, G.; Tang, F.R. Neuronal Development-Related miRNAs as Biomarkers for Alzheimer's disease, Depression, Schizophrenia and Ionizing Radiation Exposure. Curr. Med. Chem. 2020. [CrossRef]

29. Guo, L.; Zhu, Z.; Wang, G.; Cui, S.; Shen, M.; Song, Z.; Wang, J.H. microRNA-15b contributes to depression-like behavior in mice by affecting synaptic protein levels and function in the nucleus accumbens. J. Biol. Chem. 2020. [CrossRef] [PubMed]

30. Dwivedi, Y. microRNA-124: A putative therapeutic target and biomarker for major depression. Expert Opin. Ther. Targets 2017, 21, 653-656. [CrossRef]

31. Wang, S.S.; Mu, R.H.; Li, C.F.; Dong, S.Q.; Geng, D.; Liu, Q.; Yi, L.T. microRNA-124 targets glucocorticoid receptor and is involved in depression-like behaviors. Prog. Neuro-Psychopharmacol. Biol. Psychiatry 2017, 79, 417-425. [CrossRef]

32. Gu, Z.; Pan, J.; Chen, L. MiR-124 suppression in the prefrontal cortex reduces depression-like behavior in mice. Biosci. Rep. 2019, 39. [CrossRef]

33. Yang, W.; Liu, M.; Zhang, Q.; Zhang, J.; Chen, J.; Suo, L.; Chen, Q. Knockdown of miR-124 reduces depression-like behavior in rats by targeting CREB1 and BDNF. Curr. Neurovascular Res. 2020, 17, 196-203. [CrossRef] [PubMed]

34. Lo Iacono, L.; Ielpo, D.; Accoto, A.; Di Segni, M.; Babicola, L.; D'Addario, S.L.; Ferlazzo, F.; Pascucci, T.; Ventura, R.; Andolina, D. MicroRNA-34a Regulates the Depression-like Behavior in Mice by Modulating the Expression of Target Genes in the Dorsal Raphe. Mol. Neurobiol. 2020, 57, 823-836. [CrossRef]

35. Kuang, W.H.; Dong, Z.Q.; Tian, L.T.; Li, J. MicroRNA-451a, microRNA-34a-5p, and microRNA-221-3p as predictors of response to antidepressant treatment. Braz. J. Med. Biol. Res. Rev. Bras. Pesqui. Med. Biol. 2018, 51, e7212. [CrossRef] [PubMed]

36. Arimoto-Matsuzaki, K.; Saito, H.; Takekawa, M. TIA1 oxidation inhibits stress granule assembly and sensitizes cells to stressinduced apoptosis. Nat. Commun. 2016, 7, 10252. [CrossRef] [PubMed]

37. Apicco, D.J.; Ash, P.E.A.; Maziuk, B.; LeBlang, C.; Medalla, M.; Al Abdullatif, A.; Ferragud, A.; Botelho, E.; Ballance, H.I.; Dhawan, U.; et al. Reducing the RNA binding protein TIA1 protects against tau-mediated neurodegeneration in vivo. Nat. Neurosci. 2018, 21, 72-80. [CrossRef] [PubMed]

38. Vanderweyde, T.; Apicco, D.J.; Youmans-Kidder, K.; Ash, P.E.A.; Cook, C.; Lummertz da Rocha, E.; Jansen-West, K.; Frame, A.A.; Citro, A.; Leszyk, J.D.; et al. Interaction of tau with the RNA-Binding Protein TIA1 Regulates tau Pathophysiology and Toxicity. Cell Rep. 2016, 15, 1455-1466. [CrossRef] [PubMed]

39. Arisi, I.; D’Onofrio, M.; Brandi, R.; Felsani, A.; Capsoni, S.; Drovandi, G.; Felici, G.; Weitschek, E.; Bertolazzi, P.; Cattaneo, A. Gene expression biomarkers in the brain of a mouse model for Alzheimer's disease: Mining of microarray data by logic classification and feature selection. J. Alzheimer's Dis. JAD 2011, 24, 721-738. [CrossRef] [PubMed]

40. Huang, A.; Zhang, H.; Chen, S.; Xia, F.; Yang, Y.; Dong, F.; Sun, D.; Xiong, S.; Zhang, J. miR-34a expands myeloid-derived suppressor cells via apoptosis inhibition. Exp. Cell Res. 2014, 326, 259-266. [CrossRef]

41. Crowley, J.J.; Jones, M.D.; O'Leary, O.F.; Lucki, I. Automated tests for measuring the effects of antidepressants in mice. Pharmacol. Biochem. Behav. 2004, 78, 269-274. [CrossRef]

42. Karalok, H.M.; Aydin, E.; Saglam, O.; Torun, A.; Guzeloglu-Kayisli, O.; Lalioti, M.D.; Kristiansson, H.; Duke, C.M.; Choe, G.; Flannery, C.; et al. mRNA-binding protein TIA-1 reduces cytokine expression in human endometrial stromal cells and is down-regulated in ectopic endometrium. J. Clin. Endocrinol. Metab. 2014, 99, E2610-E2619. [CrossRef] [PubMed]

43. LeBlang, C.J.; Medalla, M.; Nicoletti, N.W.; Hays, E.C.; Zhao, J.; Shattuck, J.; Cruz, A.L.; Wolozin, B.; Luebke, J.I. Reduction of the RNA Binding Protein TIA1 Exacerbates Neuroinflammation in Tauopathy. Front. Neurosci. 2020, 14, 285. [CrossRef] [PubMed]

44. Phillips, K.; Kedersha, N.; Shen, L.; Blackshear, P.J.; Anderson, P. Arthritis suppressor genes TIA-1 and TTP dampen the expression of tumor necrosis factor alpha, cyclooxygenase 2, and inflammatory arthritis. Proc. Natl. Acad. Sci. USA. 2004, 101, 2011-2016. [CrossRef] [PubMed]

45. Piecyk, M.; Wax, S.; Beck, A.R.; Kedersha, N.; Gupta, M.; Maritim, B.; Chen, S.; Gueydan, C.; Kruys, V.; Streuli, M.; et al. TIA-1 is a translational silencer that selectively regulates the expression of TNF-alpha. EMBO J. 2000, 19, 4154-4163. [CrossRef] [PubMed] 
46. Ma, Z.; Liu, T.; Huang, W.; Liu, H.; Zhang, H.M.; Li, Q.; Chen, Z.; Guo, A.Y. MicroRNA regulatory pathway analysis identifies miR-142-5p as a negative regulator of TGF-beta pathway via targeting SMAD3. Oncotarget 2016, 7, 71504-71513. [CrossRef]

47. Zonenberg, A.; Leoniak, M.; Zarzycki, W. The effect of Chernobyl accident on the development of non malignant diseases. Endokrynol. Pol. 2006, 57, 38-44.

48. Loganovsky, K.N.; Bomko, M.O.; Abramenko, I.V.; Kuts, K.V.; Belous, N.I.; Masiuk, S.V.; Gresko, M.V.; Loganovska, T.K.; Antypchuk, K.Y.; Perchuk, I.V.; et al. Neuropsychobiological mechanisms of affective and cognitive disorders in the chornobyl clean-up workers taking into account the specific gene polymorphisms. Probl. Radiatsiinoi Medytsyny Ta radiobiolohii 2018, 23, 373-409. [CrossRef]

49. Aranha, M.M.; Santos, D.M.; Sola, S.; Steer, C.J.; Rodrigues, C.M. miR-34a regulates mouse neural stem cell differentiation. PLoS ONE 2011, 6, e21396. [CrossRef]

50. Jauhari, A.; Singh, T.; Singh, P.; Parmar, D.; Yadav, S. Regulation of miR-34 Family in Neuronal Development. Mol. Neurobiol. 2018, 55, 936-945. [CrossRef]

51. Jauhari, A.; Yadav, S. MiR-34 and MiR-200: Regulator of Cell Fate Plasticity and Neural Development. Neuromolecular Med. 2019, 21, 97-109. [CrossRef]

52. Liang, T.Y.; Lou, J.Y. Increased Expression of mir-34a-5p and Clinical Association in Acute Ischemic Stroke Patients and in a Rat Model. Med. Sci. Monit. Int. Med. J. Exp. Clin. Res. 2016, 22, 2950-2955. [CrossRef]

53. Wan, Y.; Liu, Y.; Wang, X.; Wu, J.; Liu, K.; Zhou, J.; Liu, L.; Zhang, C. Identification of differential microRNAs in cerebrospinal fluid and serum of patients with major depressive disorder. PLoS ONE 2015, 10, e0121975. [CrossRef]

54. Cosín-Tomás, M.; Antonell, A.; Lladó, A.; Alcolea, D.; Fortea, J.; Ezquerra, M.; Lleó, A.; Martí, M.J.; Pallàs, M.; Sanchez-Valle, R.; et al. Plasma miR-34a-5p and miR-545-3p as Early Biomarkers of Alzheimer's Disease: Potential and Limitations. Mol. Neurobiol. 2017, 54, 5550-5562. [CrossRef] [PubMed]

55. Cui, M.; Xiao, H.; Li, Y.; Dong, J.; Luo, D.; Li, H.; Feng, G.; Wang, H.; Fan, S. Total abdominal irradiation exposure impairs cognitive function involving miR-34a-5p/BDNF axis. Biochim. Biophys. Acta Mol. Basis. Dis. 2017, 1863, 2333-2341. [CrossRef]

56. Joilin, G.; Guévremont, D.; Ryan, B.; Claudianos, C.; Cristino, A.S.; Abraham, W.C.; Williams, J.M. Rapid regulation of microRNA following induction of long-term potentiation in vivo. Front. Mol. Neurosci. 2014, 7, 98. [CrossRef] [PubMed]

57. Chang, S.J.; Weng, S.L.; Hsieh, J.Y.; Wang, T.Y.; Chang, M.D.; Wang, H.W. MicroRNA-34a modulates genes involved in cellular motility and oxidative phosphorylation in neural precursors derived from human umbilical cord mesenchymal stem cells. $B M C$ Med. Genom. 2011, 4, 65. [CrossRef] [PubMed]

58. Fineberg, S.K.; Datta, P.; Stein, C.S.; Davidson, B.L. MiR-34a represses Numbl in murine neural progenitor cells and antagonizes neuronal differentiation. PLoS ONE 2012, 7, e38562. [CrossRef]

59. Morgado, A.L.; Xavier, J.M.; Dionísio, P.A.; Ribeiro, M.F.; Dias, R.B.; Sebastião, A.M.; Solá, S.; Rodrigues, C.M. MicroRNA-34a Modulates Neural Stem Cell Differentiation by Regulating Expression of Synaptic and Autophagic Proteins. Mol. Neurobiol. 2015, 51, 1168-1183. [CrossRef] [PubMed]

60. Namgyal, D.; Chandan, K.; Sultan, A.; Aftab, M.; Ali, S.; Mehta, R.; El-Serehy, H.A.; Al-Misned, F.A.; Sarwat, M. Dim Light at Night Induced Neurodegeneration and Ameliorative Effect of Curcumin. Cells 2020, 9, 2093. [CrossRef] [PubMed]

61. Welch, C.; Chen, Y.; Stallings, R.L. MicroRNA-34a functions as a potential tumor suppressor by inducing apoptosis in neuroblastoma cells. Oncogene 2007, 26, 5017-5022. [CrossRef] [PubMed]

62. Xu, L.; Zheng, Y.L.; Yin, X.; Xu, S.J.; Tian, D.; Zhang, C.Y.; Wang, S.; Ma, J.Z. Excessive Treadmill Training Enhances Brain-Specific MicroRNA-34a in the Mouse Hippocampus. Front. Mol. Neurosci. 2020, 13, 7. [CrossRef] [PubMed]

63. Córdova-Rivas, S.; Fraire-Soto, I.; Mercado-Casas Torres, A.; Servín-González, L.S.; Granados-López, A.J.; López-Hernández, Y.; Reyes-Estrada, C.A.; Gutiérrez-Hernández, R.; Castañeda-Delgado, J.E.; Ramírez-Hernández, L.; et al. 5p and 3p Strands of miR-34 Family Members Have Differential Effects in Cell Proliferation, Migration, and Invasion in Cervical Cancer Cells. Int. J. Mol. Sci. 2019, 20, 545. [CrossRef]

64. Lu, H.; Hao, L.; Yang, H.; Chen, J.; Liu, J. miRNA-34a suppresses colon carcinoma proliferation and induces cell apoptosis by targeting SYT1. Int. J. Clin. Exp. Pathol. 2019, 12, 2887-2897. [PubMed]

65. Wang, B.; He, G.; Xu, G.; Wen, J.; Yu, X. miRNA-34a inhibits cell adhesion by targeting CD44 in human renal epithelial cells: Implications for renal stone disease. Urolithiasis 2020, 48, 109-116. [CrossRef] [PubMed]

66. Kiang, J.G.; Smith, J.T.; Anderson, M.N.; Elliott, T.B.; Gupta, P.; Balakathiresan, N.S.; Maheshwari, R.K.; Knollmann-Ritschel, B. Hemorrhage enhances cytokine, complement component 3 , and caspase-3, and regulates microRNAs associated with intestinal damage after whole-body gamma-irradiation in combined injury. PLoS ONE 2017, 12, e0184393. [CrossRef]

67. Ji, Q.; Han, J.; Wang, L.; Liu, J.; Dong, Y.; Zhu, K.; Shi, L. MicroRNA-34a promotes apoptosis of retinal vascular endothelial cells by targeting SIRT1 in rats with diabetic retinopathy. Cell Cycle. 2020, 19, 1-11. [CrossRef]

68. Khanna, A.; Muthusamy, S.; Liang, R.; Sarojini, H.; Wang, E. Gain of survival signaling by down-regulation of three key miRNAs in brain of calorie-restricted mice. Aging 2011, 3, 223-236. [CrossRef]

69. Periyasamy, P.; Thangaraj, A.; Bendi, V.S.; Buch, S. HIV-1 Tat-mediated microglial inflammation involves a novel miRNA-34aNLRC5-NFkB signaling axis. Brain Behav. Immun. 2019, 80, 227-237. [CrossRef]

70. Xu, H.; Zhang, Y.; Qi, L.; Ding, L.; Jiang, H.; Yu, H. NFIX Circular RNA Promotes Glioma Progression by Regulating miR-34a-5p via Notch Signaling Pathway. Front. Mol. Neurosci. 2018, 11, 225. [CrossRef] 
71. Ma, S.; Fu, T.; Zhao, S.; Gao, M. MicroRNA-34a-5p suppresses tumorigenesis and progression of glioma and potentiates Temozolomide-induced cytotoxicity for glioma cells by targeting HMGA2. Eur. J. Pharmacol. 2019, 852, 42-50. [CrossRef] [PubMed]

72. Xu, Y.; Chen, P.; Wang, X.; Yao, J.; Zhuang, S. miR-34a deficiency in APP/PS1 mice promotes cognitive function by increasing synaptic plasticity via AMPA and NMDA receptors. Neurosci. Lett. 2018, 670, 94-104. [CrossRef] [PubMed]

73. Rayman, J.B.; Hijazi, J.; Li, X.; Kedersha, N.; Anderson, P.J.; Kandel, E.R. Genetic Perturbation of TIA1 Reveals a Physiological Role in Fear Memory. Cell Rep. 2019, 26, 2970-2983.e2974. [CrossRef] [PubMed]

74. Lowin, B.; French, L.; Martinou, J.C.; Tschopp, J. Expression of the CTL-associated protein TIA-1 during murine embryogenesis. J. Immunol. 1996, 157, 1448-1454. [PubMed]

75. Bi, J.W.; Zou, Y.L.; Qian, J.T.; Chen, W.B. MiR-599 serves a suppressive role in anaplastic thyroid cancer by activating the T-cell intracellular antigen. Exp. Ther. Med. 2019, 18, 2413-2420. [CrossRef]

76. Liu, Y.; Liu, R.; Yang, F.; Cheng, R.; Chen, X.; Cui, S.; Gu, Y.; Sun, W.; You, C.; Liu, Z.; et al. miR-19a promotes colorectal cancer proliferation and migration by targeting TIA1. Mol. Cancer 2017, 16, 53. [CrossRef] [PubMed]

77. Yang, X.; Wang, M.; Lin, B.; Yao, D.; Li, J.; Tang, X.; Li, S.; Liu, Y.; Xie, R.; Yu, S. miR-487a promotes progression of gastric cancer by targeting TIA1. Biochime 2018, 154, 119-126. [CrossRef] [PubMed] 